\title{
GARCÍA LORCA, LA MÚSICA Y LAS CANCIONES POPULARES ESPAÑOLAS
}

García Lorca, music and Spanish popular songs

Marco Antonio de la Ossa Martínez*

Resumen

Sin duda alguna, Federico García Lorca es uno de los nombres más destacados en la historia de la literatura. Pero también debe ser reconocida y valorada como merece su vertiente musical, ya que fue un buen intérprete de piano. En este sentido, conoció a los principales compositores de la España de su época. Además, fue un gran amante del flamenco y de la música tradicional y entró en contacto con cancioneros y repertorios de muy distintas épocas. Incluso, empleó numerosas canciones en sus obras teatrales y en sus montajes con la compañía La Barraca. Tampoco debemos olvidar su faceta de investigador. Así, estos serán los temas principales del presente artículo, en el que también nos centraremos en su grabación Canciones populares españolas (1931), que realizó junto con la bailaora y cantante La Argentinita.

Palabras clave: Federico García Lorca, Música Tradicional, Flamenco, Canciones populares españolas, La Argentinita.

Abstract

Undoubtedly, Federico García Lorca is one of the most prominent names in the history of literature. But he must also be recognized for his musical side, as he was a very good piano player. He met the most important Spanish composers in his days and really loved the flamenco and traditional music. He found songbooks from very different periods and even used numerous songs in his plays and productions with La Barraca. The main topic in this article is going to be his role as an investigator, because he conducted numerous studies in his travels in Granada, his province, Spain and America. And it is focused on his recording from 1931, Spanish folksongs, made in conjunction with the dancer and singer La Argentinita.

Key words: Federico García Lorca, Traditional music, Flamenco, Spanish Folksongs, La Argentinita.

\section{ACERCAMIENTO A LA FIGURA DE FEDERICO GARCÍA LORCA: VINCULACIÓN CON LA MÚSICA Y LA INVESTIGACIÓN MUSICAL}

Ciertamente, Federico García Lorca (1898-1936) es una de las grandes personalidades en la historia del arte de todos los tiempos. En este sentido y de forma lógica, es bien conocida y ha sido ampliamente estudiada su faceta de dramaturgo, poeta y ensayista; también su afición por el dibujo y la pintura. Pero, tal vez, es necesario remarcar la vertiente musical, ya que este arte tuvo una enorme importancia tanto en su vida como en su obra. Así, en su breve trayectoria, sesgada por la crudeza y locura del inicio de la guerra civil española (1936-1939), la música 
y la investigación musical, entendidas de una manera muy amplia, poseyeron una notoria relevancia.

Durante su adolescencia y en la primera etapa de su juventud, Federico era considerado como músico en su ambiente cercano, debido a que, en esos instantes, estudiaba piano y solía tocar diferentes obras en público con frecuencia. Es más: en esos momentos "su personalidad se perfilaba como la de un músico en potencia" (De Persia, 67-68), como podemos afirmar tras analizar diferentes biografias y textos dedicados al granadino. Después, cuando la literatura tomó mayor espacio en su producción, la cercanía entre poesía, teatro y música, de la misma manera que ocurriría en diferentes autores dentro de la generación en la que se inscribió, la del 27, fue muy profunda.

De esta forma, "en Federico García Lorca, música y poesía son, aún más si cabe, indisociables" (Torres, 72). Incluso, él mismo comentó en una entrevista a Pablo Suero en octubre de 1933: "ante todo, soy músico" (García Lorca, Obras Completas. III, 416). En el momento de pronunciar estas palabras, la conversación se centraba en una conferencia que el granadino iba a dictar en Buenos Aires, Cómo canta una ciudad de noviembre a noviembre. Además, el compositor Ernesto Halffter no dudó en indicar: "en mi país hay tres grandes músicos: Falla, mi maestro; yo, que soy su discípulo, y Federico García Lorca" (García Lorca, Obras Completas, 487). Por todo ello,

La obra y la vida de Lorca, en definitiva, no se explican si no se tiene en cuenta el hecho de que Federico era un músico nato. De haber vivido -no olvidemos que solo tenía 39 años cuando le fusilaron-, tal vez el poeta habría sentido la necesidad de intentar alguna composición más ambiciosa que aquellas creaciones adolescentes tan admiradas por sus compañeros (Gibson, 83).

Su vinculación musical posee un gran interés, ya que "la música fue para García Lorca una imperativa necesidad vital" (Martín, 63). José Moreno Villa (Martín, 65-66) afirmó, en la misma línea, que "Federico era un alma musical de nacimiento, de raíz, de herencia milenaria. La llevaba en la sangre como Juan Breva, Chacón o la gran "Argentinita". Daba la impresión de que manaba música, de que todo era música en su persona. Aquí radicaba su poder, su secreto fascinador".

Por tanto, hay que tener muy en cuenta el profundo trabajo que desarrolló en el campo de la investigación musical; también en el de la música para teatro y en la interpretación. En este ámbito no quedan atrás las amistades y relaciones que entabló con diferentes personalidades de enorme relevancia en el mundo de la composición, entre las que destaca su devoción, cariño y aprecio por Manuel de Falla. Esta conexión y admiración mutua fue crucial en el devenir de la música culta española del siglo XX, bajo el juicio de Jorge de Persia (67):

En la historia de la música del siglo XX español hay dos circunstancias que actúan señalando el cauce de los acontecimientos. Uno de ellos es la relación 
Falla-Pedrell que se establece a partir de 1902, punto de inflexión que llevará las propuestas y reflexiones del maestro catalán al escenario de la modernidad. La otra es la relación Falla-Lorca a partir de 1920, nueva "coincidencia intergeneracional" que va a ser fundamental para el desarrollo de las experiencias de la vanguardia — no solo musical—en España.

En el campo de la música tradicional, podemos afirmar sin temor a errores que Federico García Lorca fue, además de un enamorado de la música, un gran investigador, conocedor e intérprete de un vastísimo repertorio. "He estudiado durante diez años el folclore de mi país con sentido de poeta”, afirmó en una ocasión (García Lorca, Obras Completas. III, 459). También comentó con simpatía "soy el loquito de las canciones" (De Onís, 87). Lo cierto es que mostró una gran retentiva musical que le hizo dominar un ingente y variado catálogo. Como resumió Jorge Guillén:

La memoria de Lorca es el más rico tesoro de la canción popular andaluza. Él ha recogido muchas, letra y canto, directamente. En esa dirección, su arte corre paralelo al de su gran amigo y maestro Falla. Por algo el sentido del ritmo de este poeta alcanza una variedad, una finura prodigiosa. El ritmo es ya también arquitectura. Y no les engañe la aparente ligereza al desgaire de algunas de sus canciones. Todos sus poemas están, con cálculo perfecto, construidos, muy sabiamente estructurados (55-56).

Pero dentro de su pensamiento copiar las canciones en pentagramas no era del todo oportuno. Lo realmente valioso, bajo su juicio, era "recogerlas en gramófonos para que no pierdan ese elemento imponderable que hace más que otra cosa su belleza" (García Lorca, Obras completas. III, 459). Curioso es, cuanto menos, el término que Ramón J. Sender otorgó a esta vertiente del poeta, "folklorquismo". En este sentido, cabe resaltar la definición que Lorca realizó del término canción (459): "las canciones son criaturas, delicadas criaturas, a las que hay que cuidar para que no se altere en nada su ritmo. Cada canción es una maravilla de equilibrio, que puede romperse con facilidad: es como una onza que se mantiene sobre la punta de la aguja".

De esta manera, quizá una de las vertientes más desconocidas de Federico fue la de la musicología. Desde su infancia, su unión y apego por la música tradicional fue más que notable, debido a que en su casa oyó entonar canciones a sus mayores y a las criadas que atendieron su hogar. A continuación y como hemos mencionado, desde su etapa de estudiante efectuó numerosas visitas a regiones, pueblos y ciudades. Después, la Residencia de Estudiantes fue un importante punto de encuentro con musicólogos y manuales que, sin duda, influyeron notoriamente en este ámbito de la personalidad de Lorca. También se fijó, en gran medida, en obras del siglo XIX y en algunas secciones de distintas zarzuelas.

En definitiva, no pocos ensalzaron los conocimientos y la labor del poeta en esta línea, hecho que reflejó de forma nítida en su obra literaria. Incluso, en muchos de sus dramas dio claras indicaciones acerca de las canciones que debían interpretarse 
como parte integrante de su desarrollo. Ejemplos de ello, de los que solo incluyó sus textos, son la Canción de las niñas en Mariana Pineda y Canción de las Hilanderas, Coplas de la Criada, Copla del cortejo de bodas, Viejo romance infantil, Cantar de boda y Canción de cuna en Bodas de sangre.

Como consecuencia, todo este acervo popular inspiró y estuvo presente de forma clara en su obra literaria, como relató Valls Gorina (96):

De este organismo — el pueblo - que en España ha mantenido incontaminados e intactos sus principios culturales, se nutre gran parte de la obra de Federico García Lorca, tanto en su esfera poética ("Romancero gitano", "Poema del cante jondo", etc.) como en su ámbito escénico en el que, sus personajes, o son gente del pueblo ("Yerma", "Bodas de sangre") o es de raíz popular su intención y montaje técnico ("El Retablo de Don Perlimplín") o tiene a la mentalidad de todo un pueblo como protagonista ("La casa de Bernarda Alba").

Desde temprana edad llevó a cabo numerosas investigaciones, algunas de ellas junto al filólogo e historiador Ramón Menéndez Pidal. El trabajo del coruñés y de otros muchos musicólogos acerca del romancero, la lírica y la música tradicional española se inscriben en un movimiento de interés por este tema que se estableció en las dos primeras décadas del siglo XX y que calaría hondo en Lorca. También hubo otra corriente musical en la que se estilizaba el material musical recogido.

Como aparece reflejado en algunas de sus cartas, aprovechó los múltiples viajes que llevó a cabo por diferentes puntos de la geografía española para entrar en contacto con un repertorio muy amplio y realizar algunos trabajos de campo sobre el terreno:

En sus cartas menciona la recopilación —en Lanjarón, en los pueblos de Granada, en Santander - no solo de romances sino de canciones tradicionales, de cuentos, de "romances de crímenes"- de los que afirma haber encontrado en Granada "preciosidades"- y del anecdotario del repertorio musical de los títeres. Ya en mayo de 1918 - dos años anteshabía escrito al poeta Adriano del Valle: "me dedico a hora a recopilar la espléndida polifonía interior de la música popular granadina”, y en Impresiones y paisajes (1918) había anunciado como obra en preparación Tonadas de la Vega (Cancionero popular) (Maurer, 16).

En el mismo sentido, Tinell (79) subraya distintas "búsquedas por las Alpujarras". Por ello, el acervo popular granadino y español, entendido de una manera muy amplia, se convirtió en parte de su identidad musical. Federico de Onís definió, en global, esta vertiente del poeta, tratando, al tiempo, sus cualidades musicales:

La labor de Federico en el campo no fue la obra sistemática y metódica de un especialista, sino la de un artista que buscaba en lo popular el placer del descubrimiento e interpretación de un arte distinto, lleno de originalidad, perfección y belleza. No se utilizó, como en la poesía, esta inspiración de la música popular para la creación de una obra musical propia. Se limitaba a cantar sus amadas canciones solo, para su propio placer, acompañándolas al 
piano... Afortunadamente para la calidad de su interpretación artística de las canciones populares, no era un músico profesional. Su interpretación tenía un valor único y supremo, porque poseía un mínimun de técnica musical y un máximum de genialidad artística y de comprensión de la música popular que interpretaba. Tan ajena a toda finalidad profesional era esta labor musical suya, que, a pesar de su éxito en los círculos íntimos que la conocían, nunca se logró que escribiera la música de las canciones que tocaba de memoria con tanto entusiasmo (86).

Además, en un artículo publicado en Blanco y Negro en marzo de 1933 se comentó que Federico iba a grabar un documental dedicado a canciones, que finalmente y sin que se conozcan los motivos no se llevó a cabo:

Lorca ama el folklore español como nadie. Ahora se va a filmar una cinta de costumbres regionales. Canto, aldea, tradición, espectáculo, música. La casa productora quiere que Lorca hable ante el micrófono, explicando todos los planos, todas las variaciones de la película. Y Lorca duda. Si el film está bien, Lorca hablará. Y Lorca será feliz, enfrentado al folklore español. Su extraordinaria sensibilidad de poeta rozará suavemente, certeramente, el fono de nuestras cosas clásicas, fundiéndose con la propia sensibilidad de España (Soria, 47-48).

Además, el granadino apuntó que las canciones se parecen a las personas, ya que, normalmente, viven $\mathrm{y}$, en muchos casos, se perfeccionan, aunque algunas degeneran y se deshacen. Tal vez por todo ello nunca se decidió a transcribirlas en papel pautado. Gracias al trabajo y memoria de algunos músicos y componentes de las agrupaciones teatrales en las que se imbuyó podemos contar con algunas de ellas.

En la misma línea y gracias a la intensa actividad de la Residencia de Estudiantes, Lorca estuvo al tanto de las novedades editoriales referidas a cancioneros que se editaban en su tiempo y de otros textos antiguos. Mediante los residentes Álvaro y Jaime Disdier Mitjana, sobrinos de su editor, Rafael Mitjana, pudo conocer el Cancionero de Upsala. También entró en contacto con los artículos de música de España y Portugal que este último musicólogo escribió para la Enciclopedia de la música editada en París por De la Grave.

Otra de las compilaciones más relevantes fue el Cancionero musical de la lírica popular asturiana de Eduardo Martínez Torner, que fue publicado en Madrid en 1920. El ovetense lo presentó en una conferencia con ejemplos musicales que se celebró en la Residencia de Estudiantes. En el mismo sentido, entró en contacto con compilaciones de canciones y música tradicional de diferentes regiones. Cabe citar, en esta línea, el Cancionero de Olmeda (Burgos) o el de Ledesma (Salamanca):

Estudió también muy a fondo los cancioneros principales dedicados a coleccionar de manera mucho más completa y exacta que Pedrell lo había hecho, la música de ciertas provincias españolas. Del cancionero de Olmeda, de la provincia de Burgos, que también había de memoria, contribuyó a 
popularizar la canción Yo no quiero más premio. Del cancionero de Ledesma, de la provincia de Salamanca, sacó varias canciones que han llegado a popularizarse a través de su interpretación, entre ellas el romance de Los mozos de Monleón, el fandango Ahí tienes mi corazón y el romance de El conde de alba. Tocaba también constantemente canciones salmantinas como La Clara, El tío Vicente, El burro de Villarino, Segaba la niña y otras, que habían sido ya popularizadas por el mismo Dámaso Ledesma. También sacó muchas canciones asturianas del cancionero de aquella provincia hecho por Eduardo M. Torner (De Onís, 87).

Como vemos, tomó como referencia algunos de los textos más importantes publicados hasta este momento relacionado con la música española, entendida de una manera muy amplia. Uno de los que más influjo tuvo en el dramaturgo fue el Cancionero popular musical español de Felipe Pedrell. De los cuatro volúmenes que editó el catalán, solo uno de ellos permanece en la biblioteca que se ha conservado de la familia García Lorca. Pese a ello, está muy documentado que los conoció de primera mano y que los tuvo muy en cuenta. Al analizar esta compilación no solo entró en contacto con canciones tradicionales de distintas partes de España, sino que también conoció música de las épocas medieval, renacentista y barroca transcritas por el compositor y musicólogo.

A Lorca le motivó sobremanera algunas de las obras incluidas en este texto. En numerosas ocasiones quedó de manifiesto el hecho de que interpretó algunas de estas piezas en público repetidas veces:

Tocaba al piano muchas de las canciones populares publicadas en el libro de Pedrell como el cantar gallego Campanas de Bastabales, una canción de cuna de Badajoz, el romance gallego Estando cosendo, y muchas otras que no es necesario enumerar, pues realmente conocía al dedillo todo el cancionero y su instinto le hacía detenerse con seguro acierto en las canciones más bellas sin prejuicio alguno regional o de ninguna otra clase (De Onís, 87).

También estudió el Cancionero de Palacio, llamado Cancionero de Barbieri en honor a su investigador, Francisco Asenjo Barbieri, que lo halló en la Biblioteca del Palacio Real de Madrid. Este volumen, descubierto y trascrito en el último tercio del siglo XIX por el también compositor, fue editado en 1890 bajo el título Cancionero musical español de los siglos XV y XVI. En él se incluyen más de cuatrocientas cincuenta obras de la época renacentista compuestas, en su mayoría, en castellano, aunque hay algunos ejemplos en otros idiomas. De esta manera, se asocian con el mandato de los Reyes Católicos, y Falla bien pudo ponerle en contacto con él.

En la misma línea, hay que apuntar su conocimiento del Cancionero de Salamanca, del llamado Cancionero de Ocón y de La tonadilla escénica española de Subirá. Además, "conocía igualmente unos fascículos de música andaluza publicados en Madrid, en la calle de la Reina. Tenía también un buen conocimiento de la música catalana" (Francisco García Lorca, 426-427). 
En general y como hemos mencionado, el repertorio que Lorca manejó fue extensísimo, e incluyó canciones de muy diferentes latitudes que empleó tanto personalmente en sus recitales como en sus obras literarias. Podemos señalar, además de las ya comentadas, la zamorana El tío Babú, las asturianas Señor San Juan, Pastor que estás en el monte, Por el aire van los suspiros de mi amante o La casa del señor cura, Las Agachadas, de Segovia... Sin duda, el listado sería extensísimo.

También debemos sumar otros libros presentes en la biblioteca de la familia Lorca que pertenecieron al poeta y se albergan en la actualidad en la Fundación Federico García Lorca. Uno de ellos es Ordenamiento de menestrales hecho en las cortes de Valladolid celebrada en la era 1389 (año 1351) por D. Pedro, único de este nombre, publicado en Madrid en la imprenta Viuda M. Calero. Otro es obra de Pablo Nasarre, Fragmentos músicos repartidos en cuatro tratados: en que se hallan reglas generales, y muy necesarias para Canto Llano, Canto de Órgano, Contrapunto, y Composición. Compuestos por Fr. Pablo Nasarre y editados en 1700 en la Imprenta de Música de Madrid (se trata de un ejemplar encuadernado en pergamino). Por último, cabe citar Arte de canto-llano y órgano o prontuario músico: dividido en cuatro partes de Gerónimo Romero de Ávila, un libro publicado en Madrid en 1830, obra del racionero y maestro de melodía de la Santa Iglesia de Toledo.

Incluso, el granadino, en diferentes escritos, se atrevió a acercarse con talento a una posible definición de música en la que subrayó su carácter inexplicable (García Lorca, Obras completas, 1145):

Con las palabras se dicen cosas humanas; con la música se expresa eso que nadie conoce ni lo puede definir, pero que en todos existe en mayor o menor fuerza. La música es el arte por naturaleza. Podría decirse que es el campo eterno de las ideas... Para poder hablar de ella, se necesita una gran preparación espiritual y, sobre todo, estar unido íntimamente a sus secretos. Nadie, con palabras, dirá una pasión desgarradora como habló Beethoven en su "Sonata apassionata"; jamás veremos las almas de mujeres que Chopin nos contó en sus "Nocturnos".

\section{LORCA Y LA MÚSICA TRADICIONAL}

La música tradicional fue para Federico García Lorca un gran estímulo en el que se inspiró. Numerosos teóricos apuntan que no creó canciones, aunque otros estudiosos sí que suscriben que compuso algunos ejemplos: "de vez en cuando injertaba entre las canciones populares alguna de su propia cosecha" (Casares, 215).

En este sentido, su hermano Francisco también subrayó: "lo que él tenía de músico, su instinto, su sentido del ritmo, era suficiente para dominar a su entero gusto las melodías populares interpretadas con armonizaciones ajenas, pero en su mayor parte propias" (Francisco García Lorca, 426). Sea como fuere, está fuera de toda duda el hecho de que adaptó muchos textos a melodías ya existentes. Jorge Guillén definió así esta vertiente de su colega: 
Y se pone a cantar como el pueblo canta en su Andalucía, y se pone a poetizar, redondo universo absoluto, a su Andalucía; sierra, cielo, hombre y fantasma. No los copia; los canta, los sueña, los reinventa; en una palabra, los poetiza. ¡Pero qué integración sublime de los elementos universales en una obra que integra a su vez los grandes elementos formales de la poesía de siempre! (Guillén, 45).

En cuanto a los acompañamientos que llevó a cabo en las múltiples interpretaciones públicas que efectuó tanto frente a amigos y familiares como en reuniones y fiestas, podemos afirmar que la gran mayoría fueron realizados por él mismo. Amigos compositores, como Gustavo Durán, ayudaron en algunas de ellas, aunque Lorca siempre destacó por captar y proyectar la esencia de las canciones e imbuirlas en un ambiente sencillo pero de gran llegada para el oyente: "su interpretación tenía un gran valor único y supremo porque poseía un mínimun de técnica musical y un máximun de genialidad artística y de comprensión de la música popular que interpretaba" (De Onís, 88).

Tal vez la consecuencia más subrayada de estos trabajos de campo y de este amplísimo conocimiento de canciones se sitúa, además de en sus obras literarias, en las Canciones populares españolas, importantísimas por su repercusión en la vida musical de la España de la Segunda República (1931-1936) y su llegada al cancionero republicano de la guerra civil.

Junto con Granada, las Canciones Populares Españolas son los únicos testimonios en partitura y registrados en la Sociedad de Autores que Lorca legó. En el primer caso, se trata de una composición propia, mientras que en el segundo llevó a cabo una armonización sobre las melodías que recopiló. Así, Zorongo gitano, Sevillanas del siglo XVIII, Los cuatro muleros, Nana de Sevilla, Romance Pascual de los Peregrinitos, En el Café de Chinitas, Las morillas de Jaén, Romance de los moros de Monleón, Las tres hojas, Sones de Asturias, Aires de Castilla y Anda jaleo compusieron una terna que, como apuntamos, fue muy difundida por diversos medios por toda España y Latinoamérica. La radio también ayudó mucho en este sentido.

Realizó las grabaciones de estas canciones con la bailaora y cantante Encarnación López Júlvez, La Argentinita (1895-1941), para el sello La Voz de Su Amo en el año 1931. La compilación se compuso de cinco discos en los que Lorca tocó el piano y La Argentinita cantó y tocó las castañuelas. Al parecer, la idea partió del torero, dramaturgo y productor Ignacio Sánchez Mejías. Según Miguel Espín (2884), "le propone a Federico que aporte su inmenso caudal de conocimientos del cancionero español y su talento de hombre de teatro. A cambio, Federico vence su resistencia y logra que dé una conferencia sobre toros a estudiantes hispanos de la Universidad de Columbia".

Sobre su letra, Lorca remarcó la belleza de la lírica tradicional transmitida oralmente de generación en generación (García Lorca, Obras completas. III, 460): "¿qué más poesía? Ya podemos callarnos todos los que escribimos y pensamos poesía ante esa magnífica poesía que han hecho los campesinos". 
Desde su puesta a la venta, tuvieron un gran éxito comercial y fueron radiadas en numerosísimas ocasiones. Además, las giras que La Argentinita llevó a cabo por España y América también ayudaron a su conocimiento. La extensa lista de canciones de las que partió para sus números se compuso de un gran número de ejemplos. Entre ellos, cabe citar Sevillanas del siglo XVII, Zorongo, Los cuatro muleros, Si tu madre quiere un rey, Los peregrinitos, La Tarara, Las tres hojas, En el café de Chinitas, Entre usted, mozo, El correo de Vélez, El contrabandista...

Un buen número de críticos las recibieron de forma muy positiva. De esta manera, la edición del segundo disco fue aplaudida por distintos medios, que subrayaron su calidad y "un buen gusto intachable preside la elección de las canciones, y a ese escrupuloso criterio se une la finura y lo gracioso de su realización" (Casares, 217). También se prestó atención a

... la belleza de las canciones, por la gracia con que están interpretadas, y aún por la sencillez en su armonización tan en estilo popular, dijimos al reseñar el primer disco, y lo repetimos ahora, que esa colección constituía el más admirable ejemplo "vivo" de canciones españolas de otro tiempo que vuelven a cobrar una actualidad apasionante.

Como mencionamos, Lorca empleó muchas de estas canciones en sus obras teatrales. El diario Crítica el 15 de diciembre de 1933 publicó una entrevista con Lorca que habló de estos fines de fiesta. Comentó que la interpretación y dramatización de las canciones lo planteaba como un entretenimiento final de notable interés artístico; también subrayó la importancia de lo que él denomina canción escenificada (García Lorca, Obras completas. III, 455-456):

He querido hacer algo fino, digno, noble, con mucho sabor, pero con cierta estilización de arte. Durará alrededor de media hora, y se pasarán tres partes. La primera consistirá en la escenificación de "Los peregrinitos", así como suena, pues esta es la pronunciación popular y andaluza. Se trata de una de las canciones más difundidas del siglo XVIII español, un romance anónimo, que yo he arreglado para esta versión escénica. A continuación se pasará la conocida canción "Los cuatro muleros", y, finalmente, Lola Membrives interpretará un romance del siglo XVI, algo modernizado, que titularemos "Canción castellana". Yo considero que escenificar la canción, sobre todo estos romances, es una labor de más trascendencia que la que puede inferirse de su tono. La canción escenificada tiene sus personajes, que hablan con música, su coro, que juega el mismo papel que la tragedia griega. Por tanto, es dentro de un marco reducido, sobre todo tiempo, un espectáculo breve, pero completo, lleno de sugerencias y de bellezas.

En su puesta en escena se cuidaban los detalles en gran medida. Como consecuencia, el decorado, el vestuario y el valor que le otorgaba al cuerpo humano fueron premisas básicas en las representaciones de las canciones dramatizadas, como también las llamó (García Lorca, Obras completas. III, 461): 
Manuel Fontanals ha preparado unas decoraciones estupendas para las canciones y unos trajes que son deliciosos. Ya verán ustedes todo el espectáculo. En él se revaloriza el cuerpo humano, tan olvidado en el teatro. Hay que presentar la fiesta del cuerpo desde la punta de los pies, en danza, hasta la punta de los cabellos, todo presidido por la mirada, intérprete de lo que va por dentro.

Lo mismo afirmó en una nueva entrevista al hilo de la representación de $L a$ zapatera prodigiosa en noviembre de 1933. En este caso también incluyó diferentes canciones en el desarrollo de la obra, por lo que no solo aparecieron como fin de fiesta, sino que algunos ejemplos formaron parte integrante de sus dramas.

Respecto de la Canción de otoño en Castilla, el propio Lorca comentó que se cantaba en Burgos. Al parecer, en su escenificación se ensamblaron varias obras, entre ellas Eres hija del sueño, paloma mía y Yo no quiero más premio. En una entrevista, tras recitar algunos de los versos, exaltó su calidad literaria (García Lorca, Obras completas. III, 460):

\author{
A los árboles altos \\ los lleva el viento, \\ y a los enamorados \\ el pensamiento. \\ Digan ustedes si no es eso de una gran belleza.
}

Los fines de fiesta acontecieron en numerosas veladas. Lorca trató de respetar la letra de las canciones, aunque distribuyó los versos entre distintos cantantes y realizó diferentes armonizaciones. El poeta fue consciente del gran conocimiento de canciones que dominaba: "me jacto de conocer mucho y de ser capaz de lo que no han sido capaces todavía en España: de poner en escena y hacer gustar este cancionero de la misma manera que lo han conseguido los rusos" (García Lorca, Obras completas. III, 459). Con ello, también refería a una tradición del teatro del Siglo de Oro español:

Ha de notarse, por último, que con su fin de fiesta García Lorca no hacía más que plegase parcialmente al esquema de las representaciones teatrales del Siglo de Oro, decidiendo cerrar su obra con dos breves escenificaciones y una danza (caso de Buenos Aires), las cuales tenían carácter de broche musical del espectáculo. Se trataba de un divertimento complementario, ajeno a $L a$ Zapatera, con la cual se soldaba de manera fluida por tratarse de "escenas de canto y baile". El estilo, que no el tema, las ligaba a las ya gustadas por el espectador durante la representación de la farsa.

Lo cierto es que tuvieron una gran aceptación allí donde se representaron, tanto en América como en España: "las canciones españolas, muchas de las cuales seleccionó aquí para La Argentinita, como "Los cuatro muleros", "Los peregrinitos", etc. ¡Fines de fiesta!... Sí, fines de fiesta que se han hecho populares en toda 
Argentina" (García Lorca, Obras completas. III, 509). Ciertamente, parecieron entusiasmar al granadino, quien apuntó: "podría estarme años montando estos 'fin de fiesta"' (Soria, 138-139). En el diario El Pueblo apareció una crítica que hablaba así de estas canciones:

La línea general del tema está perfectamente ligada a la idea poética, y en el armonizar se ha tenido en cuenta la simpleza de los demás elementos originales, a fin de no crear atmósferas hostiles, que resultarían, por cierto, perjudiciales. El acompañamiento ha sido realizado para dos pianos, no siempre tratados con igual eficacia, y la faz vocal se ha tratado dentro del más elemental concepto. Reina el unísono de los coros, integrado por dos secciones de voces femeninas, y las partes solistas siguen la melodía sin aportar aditamentos de ninguna especie (Soria, 138-139).

Las canciones representadas no siempre eran las mismas, sino que solían variar atendiendo a diferentes motivos en distintas funciones. Hay que reseñar el hecho de que representara villancicos de autores de gran relevancia en la historia de la literatura española, a los que también musicalizó, aunque no conocemos la melodía asociada a los mismos:

Hay que añadir, finalmente, que el fin de fiesta se repitió casi en los mismos términos en el Coliseum de Madrid como cierre de La zapatera. Una reseña del Heraldo de Madrid (22-III-1935) nos da noticia de las piezas escogidas: "Amanecer en Castilla", que por el título y descripción escénica corresponde a la antes llamada "Canción de otoño", "Los peregrinitos", y "Retrato de Isabela", definida por el periódico como "canción epigramática" de Amadeo Vives. García Lorca, pues, no había fijado como inamovible el fin de fiesta pensado para su farsa. La canción de Vives pudo ser sugerida por Lola Membrives. Sin embargo, ya el poeta había hablado en Buenos Aires de renovar este tipo de escenificaciones, recurriendo para ello a villancicos de Góngora, Lope, Calderón y Tirso (García Lorca, Obras completas. IV, 166-167).

En un artículo publicado en Crítica se describió cómo eran los ensayos dirigidos por Federico, que se mostraba intenso en su conducción:

“¡No perder el ritmo! -y lo marca cantando y agitando acompasadamente los brazos. -Un momento; estos compases son así y para que no quepa duda, se pone al piano y el ensayo prosigue, teniéndole a él como maestro de música y de baile" (Soria, 137).

En noviembre de 1933, en una entrevista que concedió a La Razón, el dramaturgo explicó nuevos proyectos para la Navidad, en los que pretendía llevar a escena distintos villancicos de autores del Siglo de Oro:

Renovaremos estas canciones escenificados con otras, de distinto tono, que ofreceremos haciéndolas coincidir con las fiestas de Navidad y fin de año. Pienso escenificar lo que se llama "villancicos", villancicos de Góngora, de 
Lope de Vega, de Calderón, de Tirso de Molina, muy breves y muy sabrosos, con un sentido profundo y una grata envoltura, que espero serán verdaderamente gustados por el público, y muy oportunos en el momento de su exhumación (García Lorca, Obras Completas. III, 456).

En el mismo sentido y por una misiva de julio de 1929 que envió desde Nueva York hallamos otro marco de interpretación de algunas de estas canciones. El propio Lorca remarca una palabra, con la que parece destacar las múltiples peticiones e interés que despertaron en su estancia en la ciudad estadounidense sus estudios e interpretaciones. También subraya su amplio conocimiento sobre el ámbito de la canción (García Lorca, Obras completas. IV, 483-484):

$\mathrm{Y}$ allí hubo una pequeña fiesta, en el cual inevitablemente tuve que tocar y cantar al piano. No tenéis idea lo que se emocionan estos americanos con las canciones de España. Yo tengo lo que se llama un lleno. Y como ellos corren la voz a sus amigos, la casa de mister Brickell estaba de bote en bote. Claro es que habrá seguramente pocas personas que sepan más canciones que yo. Los pobres se quedan asombrados. En el invierno daré seguramente en algún salón muy elegante varias audiciones de música popular española. Es una buena propaganda de España y sobre todo de Andalucía. Así, pues, mi día tuvo un final alegre.

En el mismo sentido, en otra de las comunicaciones que llevó a cabo por carta con su familia desde los Estados Unidos en 1929 destacó la gran acogida que tuvieron las canciones que interpretó en distintas reuniones (García Lorca, Obras completas. $I V, 479-480)$ :

Había un muchachillo que cantó cantos religiosos. Yo me senté en el piano y también canté. Y no quiero deciros lo que les gustaron mis canciones. Las "moricas de Jaén", el "no salgas, paloma, al campo", y "el burro" me las hicieron repetir cuatro o cinco veces.

Como hemos mencionado, La Argentinita, tras formar su propia compañía en 1932, realizó diferentes producciones con las Canciones populares españolas como base de propuestas coreográficas tanto en España como en el extranjero. Además, realizó distintas investigaciones acerca de diversas danzas españolas, por lo que recopiló un buen número de bailes tradicionales en diferentes lugares de la geografía española que, con posterioridad, las adaptó e interpretó. Al parecer, "escribió un libro sobre bailes españoles, todavía inédito" (Vaquero, 2).

\section{LAS CANCIONES POPULARES ESPAÑOLAS}

a) Las tres hojas: 
Las tres hojas

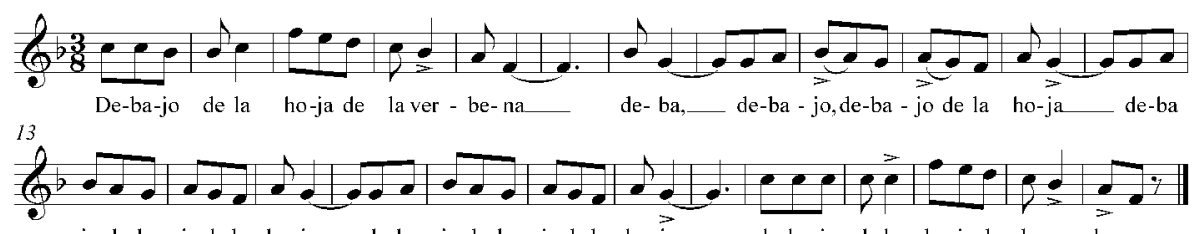

jo,de-ba-jodela ho-ja de-ba-jo,de-ba-jodela ho-ja de-ba-jo de la ho-ja de laver - be-na

1

Debajo de la hoja

de la verbena

tengo a mi amante malo:

¡Jesús, qué pena!

2

Debajo de la hoja

de la lechuga

tengo a mi amante malo

con calentura.

3

Debajo de la hoja del perejil

tengo a mi amante malo

y no puedo ir.

(García Lorca, Obras completas, 817)

b) Los cuatro muleros:

\section{Los cuatro muleros}

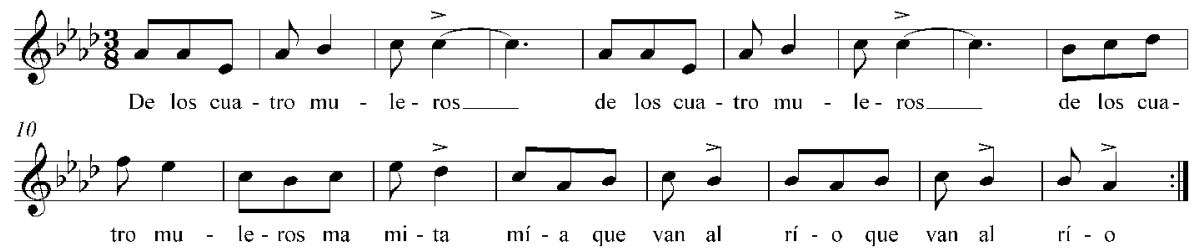

1

De los cuatro muleros

que van al campo,

el de la mula torda

moreno y alto. 


\section{2}

De los cuatro muleros

que van al agua,

el de la mula torda

me roba el alma.

3

De los cuatro muleros

que van al río,

el de la mula torda

es mi marío.

4

¿A qué buscas la lumbre

la calle arriba,

si de tu cara sale

la brasa viva?

(García Lorca, Obras completas, 818) Albaicín:

Lorca comentó que se trataba de una canción que se cantaba en Navidad en el

[Los cuatro muleros] es la canción típica de la Navidad en el Albaicín. Se canta únicamente por esa fecha, cuando hace frío. Es un villancico pagano, como son paganos casi todos los villancicos que canta el pueblo. Los villancicos religiosos solo los cantan en las iglesias y las niñeras para adormecer a los niños. Es curioso este pagano villancico de Navidad, que denuncia el sentido báquico de la Navidad en profunda emoción y contenido social (García Lorca, Obras completas. III, 460).

Además, en una crítica relativa a la edición del disco en el que se incluía, el cuarto de la serie, el periodista se refiere a Los cuatro muleros indicando que es una canción "deliciosa y su texto parece albergar ya gérmenes de la poesía andaluza, desde Juan Ramón Jiménez al propio García Lorca” (Casares, 218).

Lorca también la escenificó en sus fines de fiesta, empleando como emplazamiento un fondo de serranía, en el que

...exquisitas, al pie de ese telón, cuatro campesinas de vestidos armonizados en sus tonos, sirviendo de cuadro a otra figura central arrogantísima. Tienen las unas el rostro semioculto por panderetas, la otra una actitud instante de baile. Y con la canción el baile comienza, con pasos como de marcha, hacia delante y hacia atrás, en diagonal siempre. Baila solemnemente la figura eje. Las otras comentan con la canción misma y con el juego de los panderos hasta llegar a un jaleo final en que la danza de la protagonista se aviva (García Lorca, Obras completas, 176).

En el diario El Día de Montevideo el 22 de febrero de 2012 se alude a su representación y a su texto: 
...esta versión de "Los cuatro muleros" triunfa el paralelismo estrófico de las seguidillas, sin necesidad de recurrir a la nota vulgar del contraste en el bordón: "Ay, que me he equivocao/que el de la mula torda,/mamita mía,/es mi cuñao". En consonancia con La Zapatera Prodigiosa, y quizá el juego no fuera casual, el mayor cantado en el villancico no se salía un punto del matrimonio (García Lorca, Obras completas, 169).

c) En el café de Chinitas:

\section{En el café de Chinitas}

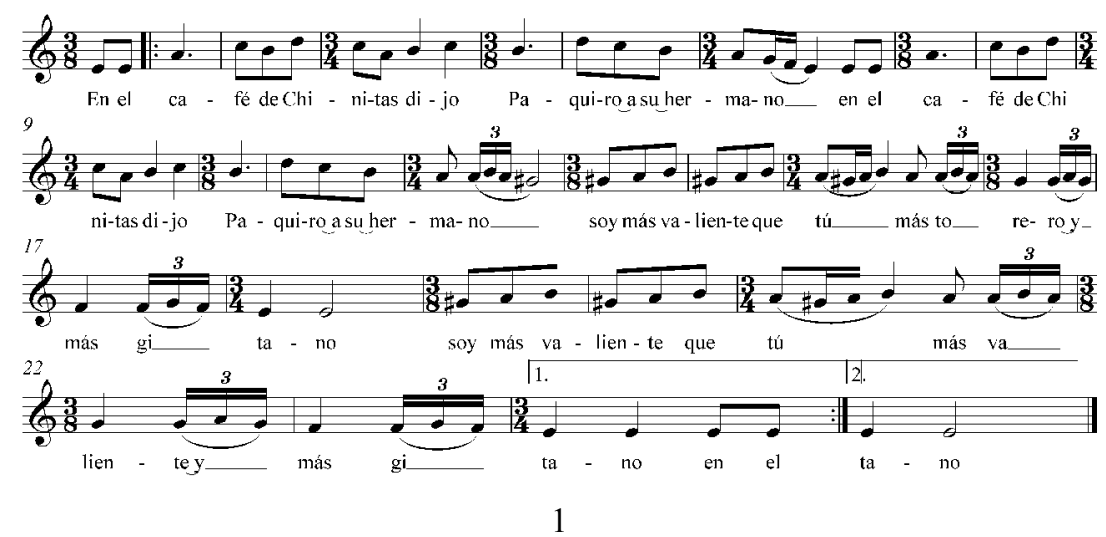

En el café de Chinitas dijo Paquiro a su hermano: "Soy más valiente que tú más torero y más gitano". 2

En el café de Chinitas dijo Paquiro a Frascuelo: "Soy más valiente que tú, más gitano y más torero.”. 3

Sacó Paquiro el reló y dijo de esta manera: "Este toro ha de morir antes de las cuatro y media.". 4

$\mathrm{Al}$ dar las cuatro en la calle se salieron del café y era Paquiro en la calle un torero de cartel.

(García Lorca Obras completas 819) 
d) Los pelegrinitos:

\section{Los pelegrinitos}

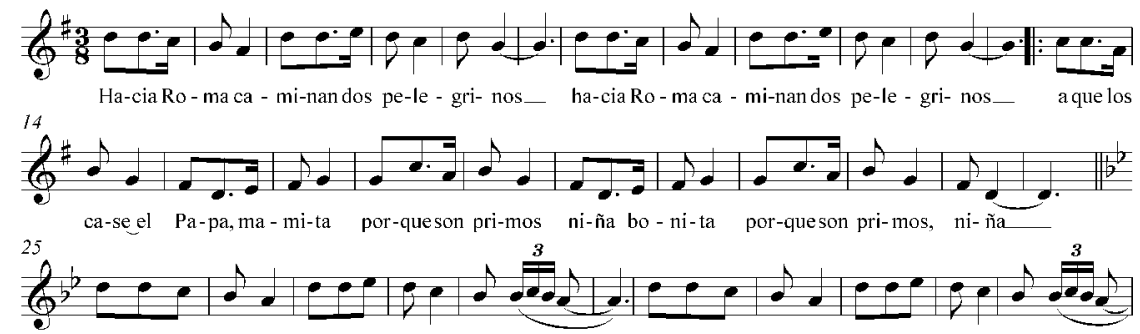

Le hapre-gun - ta-doel Pa-pacó - mo se - lla- man

le hapre-gun - ta-do el Pa-paco-mose

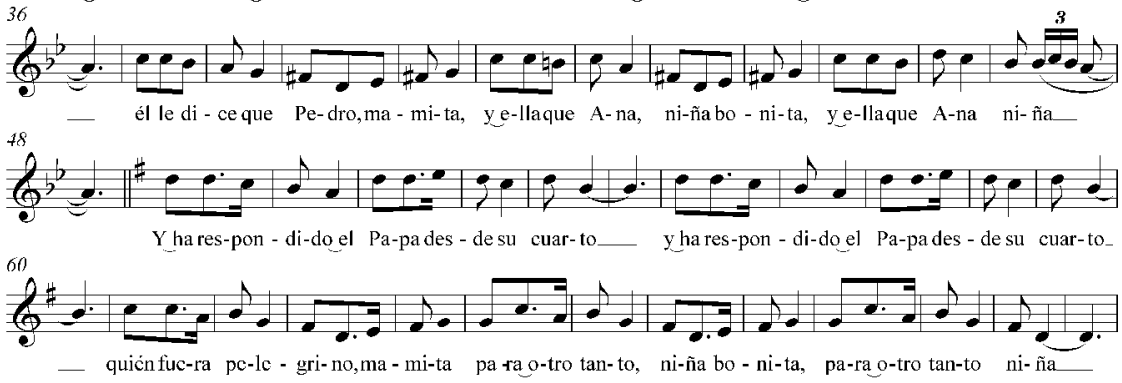

Hacia Roma caminan dos pelegrinos,

a los que case el Papa porque son primos.

Sombrerito de hule lleva el mozuelo, y la pelegrinita, de terciopelo.

Al pasar por el puente de la Victoria, tropezó la madrina cayó la novia.

Han llegado a Palacio, suben arriba,

y en la sala del Papa los desaniman.

Le ha preguntado el Papa cómo se llaman.

Él le dice que Pedro y ella que Ana. 


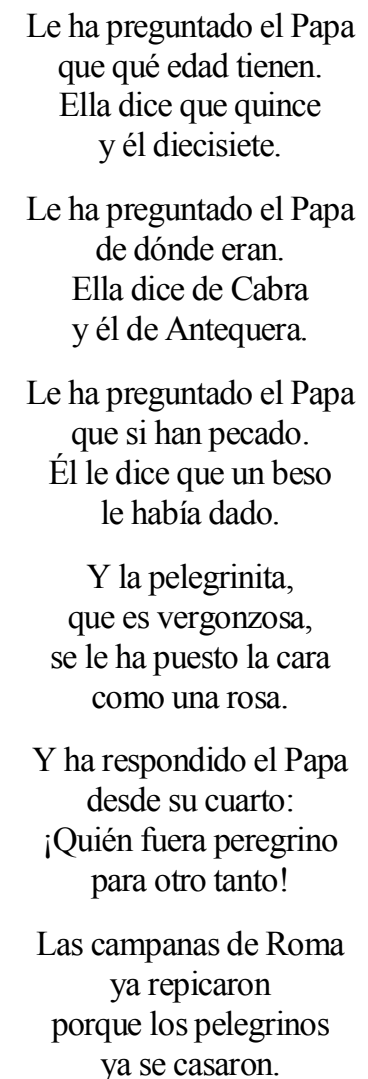

(García Lorca, Obras completas, 820-821)

Al parecer, esta canción está presente en el romancero de Antequera, aunque es frecuente encontrarla en muy diferentes puntos de España. El propio Lorca dijo en una entrevista que se cantaba todavía en Granada, y aludió a diferentes versiones de las que partió:

"Los pelegrinitos" se canta todavía en Granada. Hay diversas variantes, de las cuales yo he desarrollado dos en esta escenificación; una tiene el ritmo alegre y es propia de las vegas granadinas; otra es melancólica y proviene de la Sierra. Con la variante de las vegas, comienzo y termino la canción (García Lorca, Obras completas. III, 459).

Pero, como ocurrió con gran cantidad de los ejemplos reunidos en las Canciones populares españolas, la grabación de Lorca y La Argentinita hicieron muy popular esta canción. Textualmente, para Francisco López,

Los textos recogidos en Antequera ofrecen la forma métrica de la copla cuarteta asonante (y consonante) $7^{\mathrm{a}}$. 5b. 7c. 5b., o sea, la seguidilla simple en serie continua, con cambio de rima en cada copla. Esta canción fue recogida 
mezclada entre los romances sin que las cantoras hiciesen distinción alguna entre ambas formas métricas (López Estrada, 258-259).

En una de sus representaciones como fines de fiesta, el escenógrafo Manuel Fontanals creó "una imagen del palacio Vaticano consistente en una serie de arcada en perspectiva, con algo de lo que imaginaría un hombre de campo. Lo mismo ha concebido Fontanals para la confección de los trajes, en los que sin precisar lugar ni fecha se fija una imagen de pequeña porcelana" (García Lorca, Obras completas, 171).

d) Sevillanas del siglo XVIII:

\section{Sevillanas del s. XVIII}

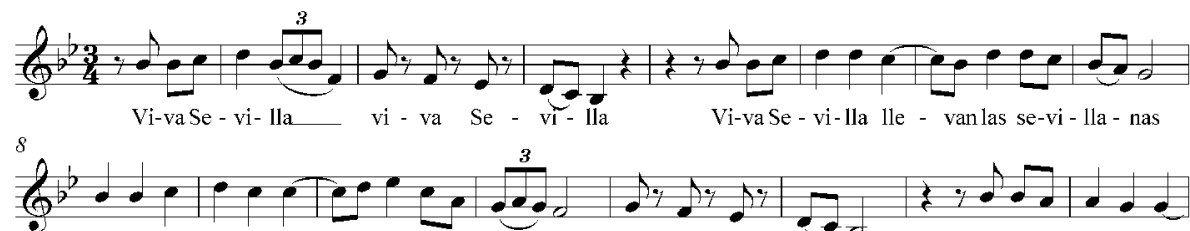

en la man ti-lla un__le-tre-roque di_ce vi - va Se - vi lla Vi-vaTri-a-na vi-

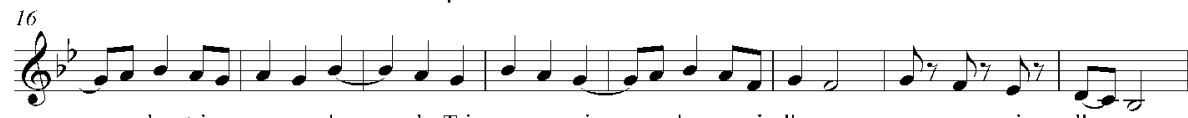

- van los tri-a - ne-ros los__ de Tri - a - na vi_ vanlos se-vi-lla-nos y se - vi - lla_nas

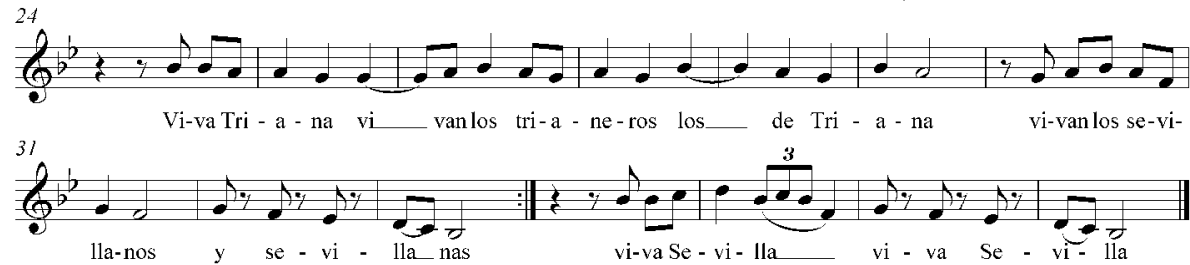

1

¡Viva Sevilla!

Llevan las sevillanas

en la mantilla

un letrero que dice:

¡Viva Sevilla!

¡Viva Triana!

¡Vivan los trianeros,

los de Triana!

¡Vivan los sevillanos

y sevillanas!

2

Lo traigo andando.

La Macarena y todo

lo traigo andando. 
Lo traigo andando; cara como la tuya no la he encontrado.

La Macarena y todo

lo traigo andado. 3

Ay río de Sevilla, qué bien pareces

lleno de velas blancas y ramas verdes.

(García Lorca, Obras completas, 822-823)

A propósito de esta canción, incluida en el segundo disco, en algunos medios se señaló que Lorca las supuso del siglo XVIII atendiendo a la tradición, aunque no se puede asegurar este origen. Posee un metro regular que, al parecer, no se daba de la misma manera en los primeros tiempos de la seguidilla. Sea como fuere, sí que poseen cierta antigüedad. En cuanto a la procedencia de la melodía, de metro regular $(7+5)$, parece ser una variante del Cancionero que Ocón había editado años antes.

Esta seguidilla, siguiendo el mismo artículo, parece que aparece reflejada en una obra de Lope de Vega, Lo cierto por lo dudoso, de 1625. A partir de ese momento pasó a hacerse muy conocida.

e) Las morillas de Jaén:

Las morillas de Jaén

Canción popular del s. XV

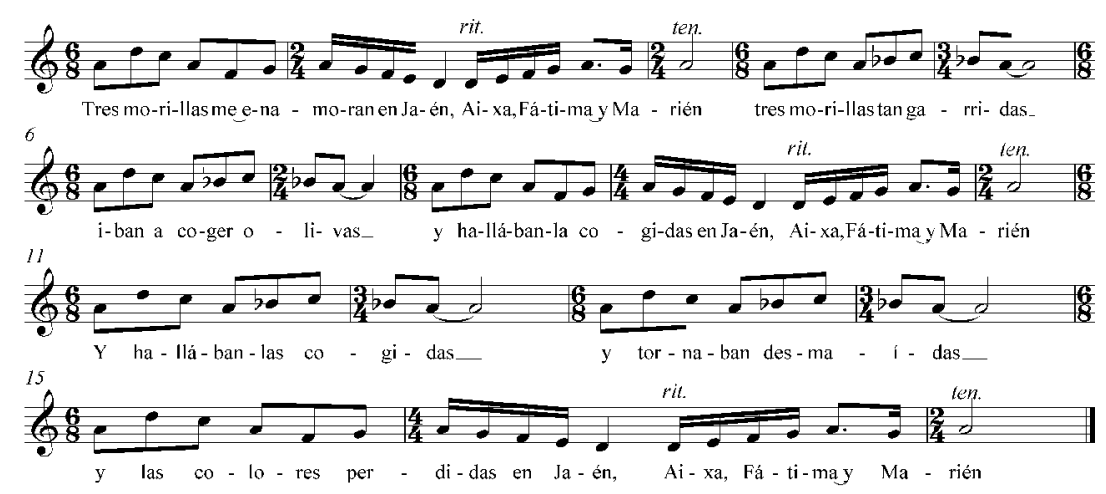

Tres moricas me enamoran en Jaén:

Axa y Fátima y Marién.

Tres moricas tan garridas iban a coger olivas, 
y hallábanlas cogidas en Jaén:

Axa, Fátima y Marién.

Tres moricas tan lozanas iban a coger manzanas y hallábanlas tomadas en Jaén:

Axa y Fátima y Marién.

Díjeles: ¿Quién sois, señoras, de mi vida robadoras?

Cristianas que éramos moras en Jaén:

Axa y Fátima y Marién.

(García Lorca, Obras completas, 824)

Esta canción está presente en el Cancionero de Palacio, del siglo XV, aunque en esta compilación aparece sin texto. En la Sociedad de Autores de Variedades, Lorca señaló que la había transcrito y armonizado. El texto, así, bien pudo recogerse en alguno de sus trabajos de campo, aunque, atendiendo a la belleza de su poesía, bien pudo haberlo escrito él, aunque es tan solo una hipótesis.

f) Anda, jaleo:

Anda, jaleo

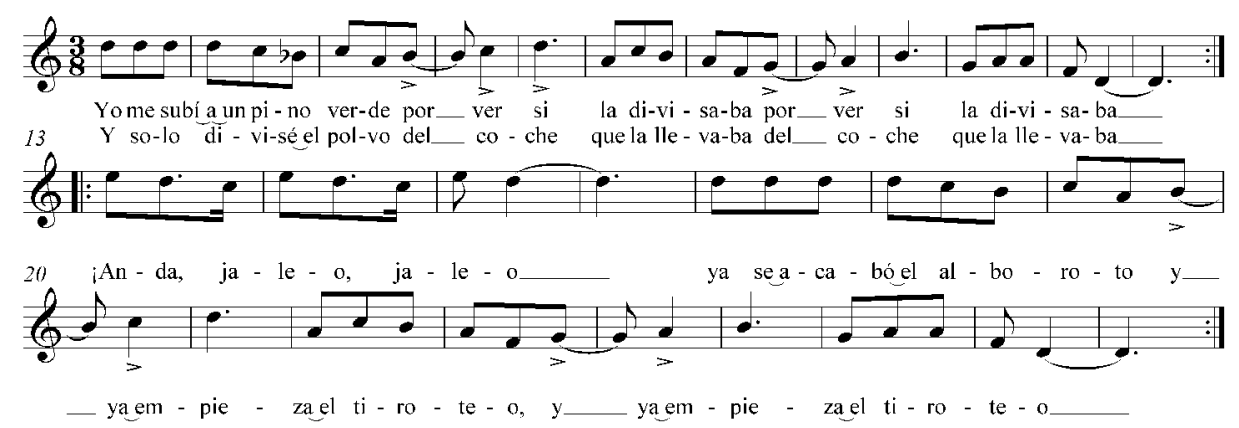

Yo me subí a un pino verde por ver si la divisaba y solo divisé el polvo del coche que la llevaba.

Anda jaleo, jaleo; ya se acabó el alboroto y ahora empieza el tiroteo. 
En la calle de los Muros mataron a una paloma.

Yo cortaré con mis manos las flores de su corona.

Anda jaleo, jaleo; ya se acabó el alboroto y ahora empieza el tiroteo.

No salgas, paloma, al campo, mira que soy cazador y si te tiro y te mato para mí será el dolor, para mí será el quebranto.

Anda jaleo, jaleo; ya se acabó el alboroto y ahora empieza el tiroteo.

(García Lorca, Obras completas, 825)

g) Los mozos de Monleón (Ledesma, Cancionero Salmantino):

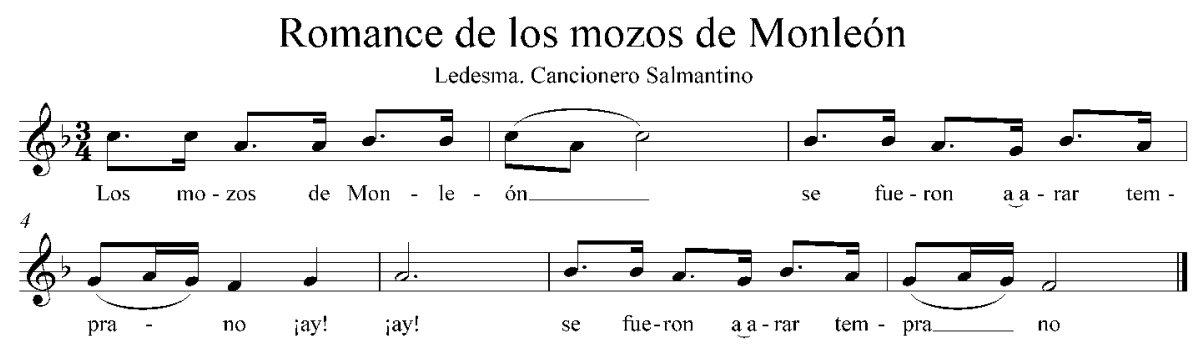

Los mozos de Monleón se fueron a arar temprano, para ir a la corrida, y remudar con despacio. Al hijo de la viuda el remudo no le ha dado. -Al toro tengo que ir, aunque lo busque prestado.

-Permita Dios, si lo encuentras, que te traigas en un carro, las abarcas y el sombrero de los siniestros colgando. Se cogen los garrochones, marchan las navas abajo, preguntando por el toro, 
y el toro ya está encerrado.

En el medio del camino,

al vaquero preguntaron.

- ¿Qué tiempo tiene el toro?

- El toro tiene ocho años.

- Muchachos, no entréis a él;

mirar que el toro es muy malo

que la leche que mamó

se la di yo por mi mano.

Se presentan en la plaza

cuatro mozos muy gallardos;

Manuel Sánchez llamó al toro;

nunca le hubiera llamado,

por el pico de una abarca

toda la plaza arrastrado;

cuando el toro lo dejó

ya lo ha dejado muy malo.

- Compañeros, yo me muero;

amigos, yo estoy muy malo;

tres pañuelos tengo dentro

$y$ este que meto son cuatro.

- Que llamen al confesor,

para que vaya a auxiliarlo.

No se pudo confesar

porque estaba ya expirando.

Al rico de Monleón

le piden los bueis y el carro,

pá llevar a Manuel Sánchez

que el torito le ha matado.

A la puerta de la viuda

arrecularon el carro.

- Aquí tenéis vuestro hijo

como lo habéis demandado

(García Lorca, Obras completas, 826-827). 
h) Nana de Sevilla:

Nana de Sevilla

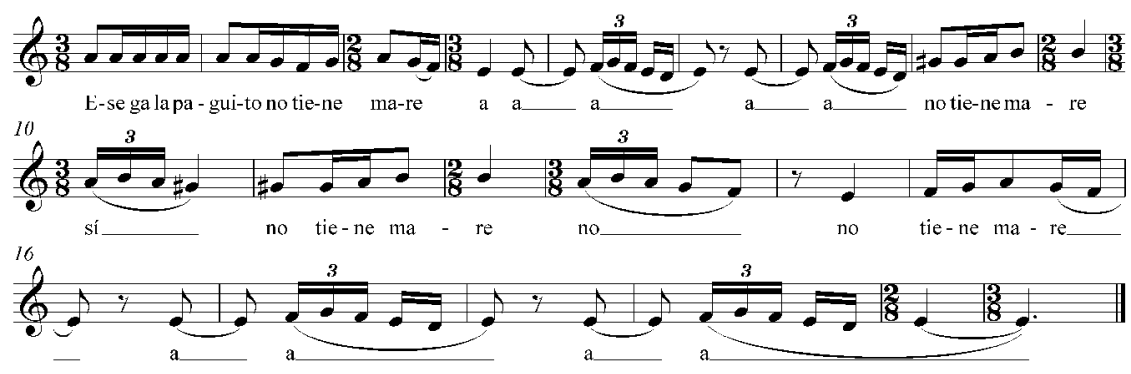

Este galapaguito no tiene mare;

lo parió una gitana

lo echó a la calle.

No tiene mare, sí;

no tiene mare, no;

no tiene mare,

lo echó a la calle.

Este niño chiquito

no tiene cuna;

su padre es carpintero

y le hará una.

(García Lorca, Obras completas, 826-827)

i) Los reyes de la baraja:

Los reyes de la baraja
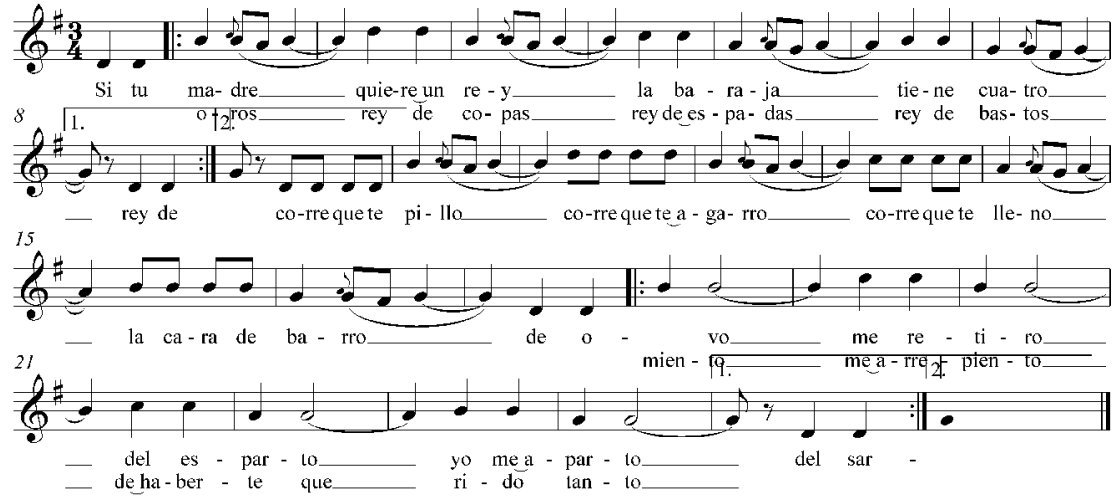
Si tu madre quiere un rey

la baraja tiene cuatro:

rey de oros, rey de copas,

rey de espadas, rey de bastos.

Corre que te pillo,

corre que te agarro,

mira que te lleno

la cara de barro.

Del olivo

me retiro

del esparto

yo me aparto,

del sarmiento

me arrepiento

de haberte querido tanto.

(García Lorca, Obras completas, 829)

j) La Tarara:

\section{La Tarara}

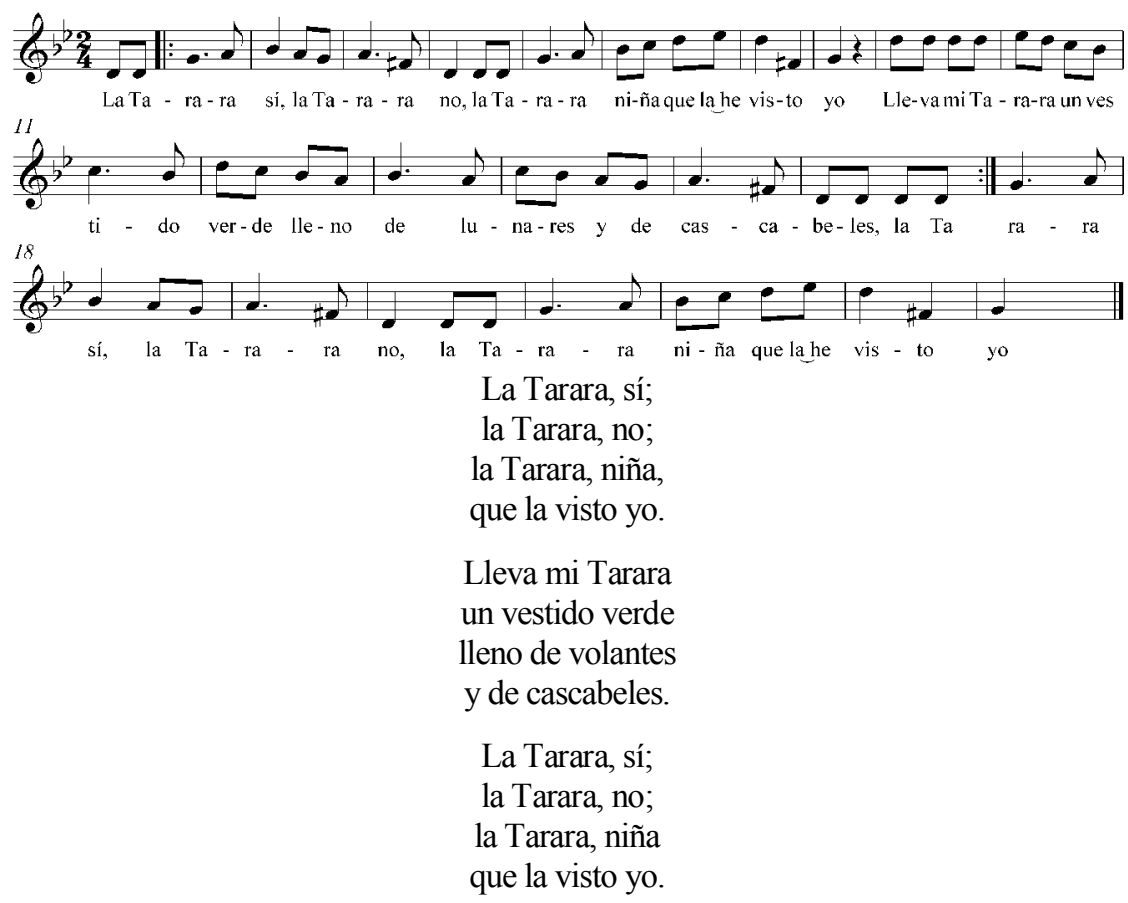


Luce mi Tarara

su cola de seda

sobre las retamas

y la hierbabuena.

Ay, Tarara loca.

Mueve la cintura

para los muchachos

de las aceitunas.

(García Lorca, Obras completas, 830)

k) Zorongo:

Zorongo gitano

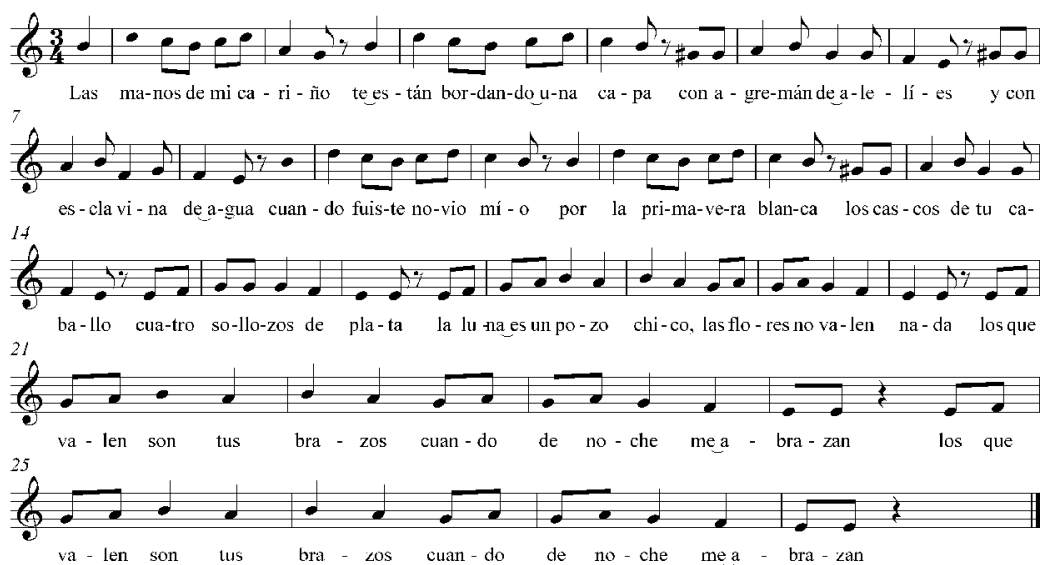

Las manos de mi cariño

te están bordando una capa

con agremán de alhelíes

y con esclavina de agua.

Cuando fuiste novio mío,

por la primavera blanca,

los cascos de tu caballo

cuatro sollozos de plata.

La luna es un pozo chico,

las flores no valen nada,

lo que valen son tus brazos

cuando de noche me abrazan,

lo que valen son tus brazos

cuando de noche me abrazan

(García Lorca, Obras completas, 831). 
1) Romance de don Boyso:

Romance de don Boyso

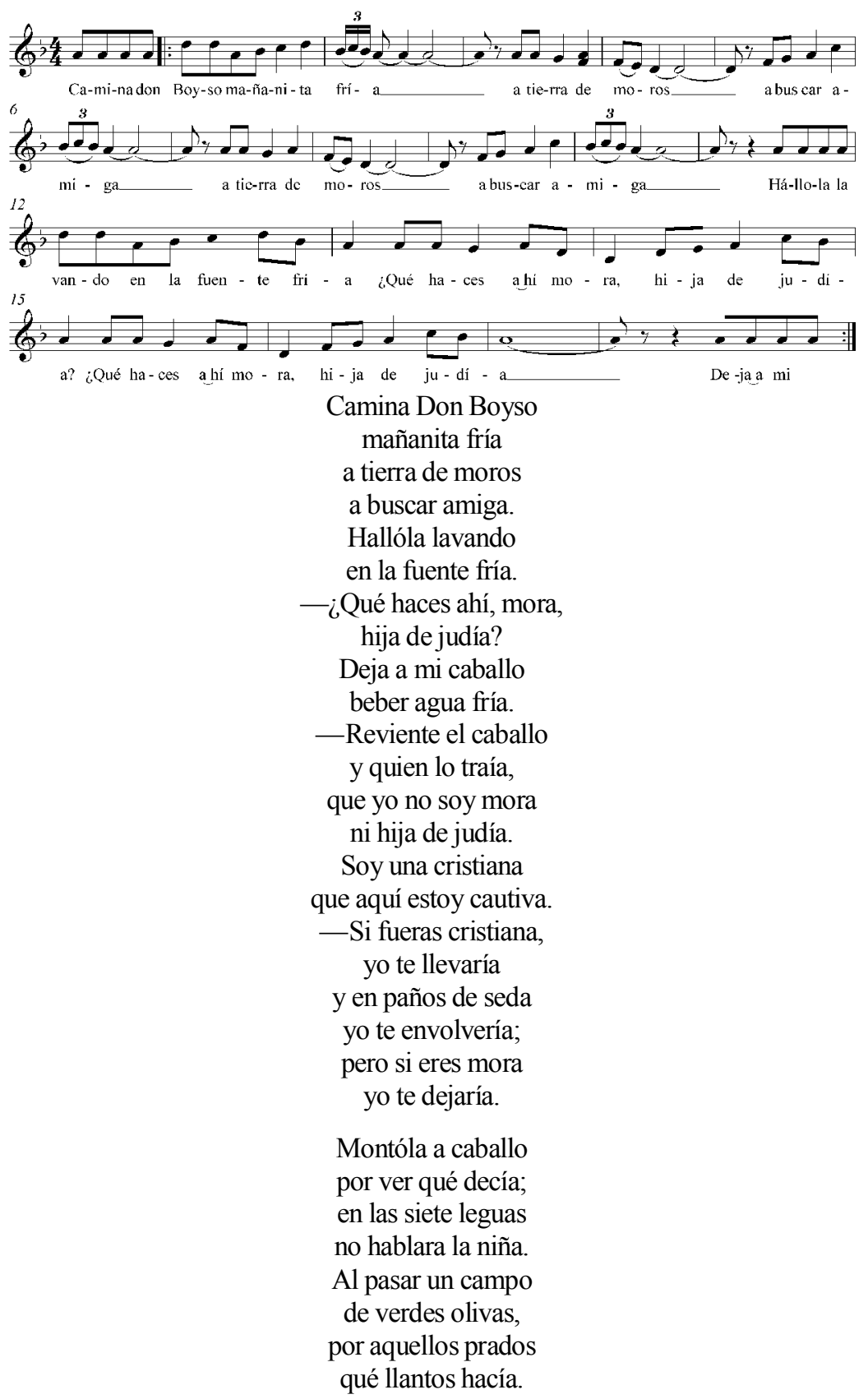




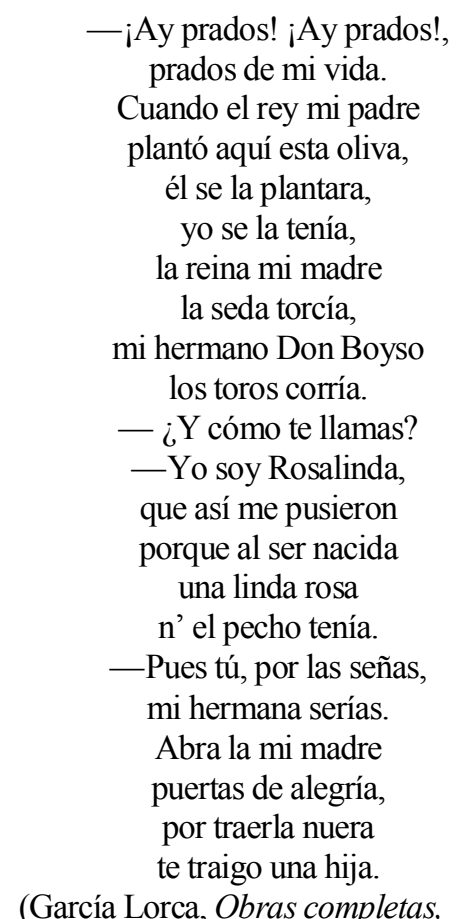

¡Ay prados! ¡Ay prados curno de mi vida. plantó aquí esta oliva, él se la plantara, yo se la tenía, la seda torcía, mi hermano Don Boyso los toros corría. - ¿Y cómo te llamas? -Yo soy Rosalinda, que así me pusieron prque al ser nacida n' el pecho tenía. -Pues tú, por las señas, mi hermana serías. Abra la mi madre (García Lorca, Obras completas, 833)

m) Nana:

\author{
Duérmete, niñito mío, \\ que tu madre no está en casa; \\ que se la llevó la Virgen \\ de compañera de casa \\ (García Lorca, Obras Completas, 824).
}

\title{
4. CONCLUSIONES
}

Como hemos tratado de esbozar en este artículo, la relación de Lorca con la música es muy estrecha y definitoria de su obra y su personalidad; también magnética para cualquier investigador. Así, hemos tratado de dibujar unos breves trazos acerca de su gran relación con el acervo tradicional. Lo cierto es que, en su vida, el arte de Orfeo ocupó un lugar de privilegio ya desde sus primeros años de estudiante, en los que era considerado como músico y su vocación caminaba más cercana al piano que a la pluma y al papel.

Pero incluso cuando se decantó en mayor medida por la literatura, la música ocupó un espacio muy relevante en su catálogo y en su devenir por el mundo: no solo se relacionó con grandes personalidades musicales de su momento, sino que fue muy frecuente verle cantar y tocar el piano. Aparte de las composiciones que inició, 
también se dedicó a la investigación, e incluyó en muchos de sus teatros un buen número de canciones. En este sentido, su trabajo en la compañía de teatro aficionado La Barraca fue muy subrayado, ya que la música poseyó una enorme importancia en sus montajes.

Además, la edición de las Canciones populares españolas en el sello La Voz de Su Amo junto a La Argentinita en 1931 supuso un nuevo punto de inflexión en su carrera musical. No solo fueron radiadas y escuchadas en numerosos puntos del globo, sino que también las tomó como punto de partida para llevar a cabo diferentes propuestas en sus representaciones teatrales a modo de fin de fiesta.

En definitiva, lo cierto es que su nivel literario destaca por sí solo, aunque no hay que olvidar su gran temperamento musical. Quizá se deba, como apuntó Jorge Guillén (14):

Todos sabemos que en Federico resaltaba un gran temperamento de músico, acrecentado por la vigilia estudiosa. Habría podido ser compositor si se lo hubiese propuesto... En música fue tal vez donde el gusto de Federico se refinó con más pureza.

\author{
Universidad de Castilla-La Mancha, Cuenca* \\ Facultad de Educación \\ C/ Canaleja n $n^{\circ}$-1A 16001 Cuenca (España) \\ marcoantoniodela@gmail.com
}

\title{
OBRAS CITADAS
}

Casares Rodicio, Emilio (Ed). La música en la Generación del 27. Homenaje a Lorca. 1915-1939. Madrid: Ministerio de Cultura, 1986.

De Onís, Federico. "Lorca, folklorista". En: La música en la generación del 27. Homenaje a Lorca. Madrid: Ministerio de Cultura, 1986: págs. 84-88.

De Persia, Jorge. "Lorca, Falla y la Música. Una coincidencia intergeneracional". En: Zapke, Susana (Ed.). Falla y Lorca. Entre la tradición y la vanguardia. Kassel, Edition Reichenberger, 1989: págs. 67-89.

Espín, Miguel. "La Argentinita: vida y obra". Candil, Revista de Flamenco. Peña Flamenca de Jaén 113 (1997): 2879-2887.

García Lorca, Federico. Obras completas. III. Barcelona: RBA, 2006.

- Obras completas. IV. Barcelona: RBA, 2005.

-Obras completas. Bilbao: Aguilar, 1977.

García Lorca, Francisco. Federico y su mundo. Madrid: Alianza, 1999

Gibson, Ian. "Lorca y la música". En: Casares Rodicio, Emilio (Ed.). La música en la generación del 27. Homenaje a Lorca. Madrid: Ministerio de Cultura (1986): págs. 81-83. 
Guillén, Jorge. "Prólogo”. García Lorca, Federico. Obras completas. Bilbao: Aguilar, 1977: págs. 5-15.

López Estrada, Francisco. "El romance de 'Don Bueso' y la canción de 'La Pelegrinita' en el cancionero folklórico de Antequera". En: López de Abiada José Manuel y López Bernasocchi Augusta (eds.). De los romancesvillancicos a la poesía de Claudio Rodríguez. 22 ensayos sobre las literaturas española e hispanoamericana en homenaje a Gustav Siebenmann, Madrid, José Esteban Ed., 1984: págs. 253-263.

Martín Moreno, Antonio. "La generación literaria del 27 y la música: Jorge Guillén y Federico García Lorca”. En: García Gallardo, Cristóbal L.; Martínez González, Francisco; Ruiz Hilillo, María (coord.). Los músicos del 27. Granada: Universidad de Granada, CDMA, 2010: págs. 53-69.

Maurer, Christopher. Apostillas textuales sobre suites y canciones. L'imposible/ posible di Federico García Lorca. Napoli: Edizioni Scientifiche Italiane, 1989: págs. 77-90.

Soria Olmedo, Andrés. Treinta entrevistas a Federico García Lorca. Madrid: Aguilar, 1989.

Tinell, Roger D. Federico García Lorca y la música. Madrid: Fundación Juan March, 1993.

Torres Clemente, Elena. "Vocaciones cruzadas: músicos y poetas de la Generación del 27'. En: García Gallardo, Cristóbal L.; Martínez González, Francisco; Ruiz Hilillo, María (coord.) Los músicos del 27. Granada: Universidad de Granada, 2010: págs. 70-92.

Vaquero, Pedro. "Federico García Lorca; La Argentinita". En: Colección de Canciones Populares Españolas. Madrid: Sonifolk, 1994: págs. 2-9. 